\title{
Vitamin D deficiency in primary care
}

\author{
Deficitul de vitamină D în asistenţa medicală primară
}

\author{
Mihaela Adela Iancu ${ }^{1,2}$, Cristian Gabriel Bejan ${ }^{1,2}$, Alexandra Ana Maria Stănescu' ${ }^{1}$, \\ Cristian Constantin Ştefani ${ }^{1,2}$, Dumitru Matei ${ }^{1,3}$, Camelia Cristina Diaconu ${ }^{1,4}$ \\ ${ }^{1}$ Universitatea de Medicină şi Farmacie „Carol Davila“, Bucureşti, România \\ ${ }^{2}$ Cabinet medical individual medicină de familie, Bucureşti, România \\ 3Institutul Naţional pentru Sănătatea Mamei şi Copilului „Alessandrescu-Rusescu“, \\ Bucureşti, România \\ ${ }^{4}$ Spitalul Clinic de Urgenţă Floreasca, Bucureşti, România
}

\begin{abstract}
Vitamin $D$ is required to maintain normal blood levels of calcium and phosphate, which are in turn needed for the normal mineralization of bone, also play a role in muscle function, nerve conduction, the immune system and general cellular function in all cells of the body. Populations at risk for vitamin D deficiency are infants, adolescents, eldery, pregnant and lactating women. The actions of the vitamin $D$ hormone 1,25dihydroxyvi-tamin D3 $(1,25(\mathrm{OH}) 2 \mathrm{D} 3)$ are mediated by the vitamin D receptor (VDR), a ligand-activated transcription fac-tor that functions to control gene expression. Epidemiological data underline a strong correlation between vitamin D deficiency and higher risk for chronic inflammatory illnesses or autoimmune diseases. Evidence is not sufficiently to draw conclusions regarding the benefits of vitamin D supplementation for the prevention of cancer. Literature increasingly supports the inverse relationship of vitamin $\mathrm{D}$ level and diabetes, metabolic syndrome, cardiovascular disease mortality.
\end{abstract}

Keywords: vitamin D, deficiency, autoimmune diseases, cardiovascular disease

\section{REZUMAT}

Vitamina $D$, necesară pentru menţinerea normală a homeostaziei calciului şi fosforului, are un rol esenţial nu doar în mineralizarea normală a oaselor, ci şi în contracţia musculară, conducerea impulsului nervos, asigurarea funcţiei sistemului imunitar, precum şi în funcţionarea normală a celorlalte celule ale organismului. Grupele de populaţiile cu risc de deficit de vitamină D sunt reprezentate de sugari, adolescenţi, vârstnici, femei însărcinate şi femei care alăptează. Acţiunile vitaminei D, prin 1,25-dihidroxivitamina D3, sunt mediate de către receptorul vitaminei D (VDR), un factor de transcripţie activat de ligand, care funç̧ionează pentru a controla exprimarea genei. Datele epidemiologice subliniază o corelaţie puternică între deficitul de vitamină D şi riscul crescut de boli inflamatorii cronice sau boli autoimune. Dovezile nu sunt suficient pentru a trage concluzii cu privire la beneficiile suplimentelor de vitamina D pentru prevenirea cancerului. Studiile arată existenţa unei relaţii inverse între nivelul seric de vitamină D şi apariţia diabetului zaharat, a sindromului metabolic sau a creşterii mortalităţii prin boli cardiovasculare.

Cuvinte cheie: vitamina D, deficit, boli autoimune, boli cardiovasculare

Vitamina D, necesară pentru menținerea normală a homestaziei calciului şi fosforului, are un rol esențial nu doar în mineralizarea normală a oaselor, ci şi în contracția musculară, conducerea impulsului nervos, asigurarea funcției sistemului imunitar, precum şi în funcționarea normală a celorlalte celule ale organismului.

Între descrierea simptomelor şi semnelor din rahitism şi descoperirea cauzei care produce această boală au trecut câteva secole. Sir Edward Mellan- 
by, medic şi cercetător britanic, este primul care a descoperit că rahitismul se poate vindeca cu ulei din ficat de cod şi a presupus că vitamina A, identificată deja, este responsabilă de vindecarea rahitismului. Cercetările au fost continuate de Elmer McCollum, medic american, de origine scoțiană, care a observat că distrugerea vitaminei A, prin barbotarea oxigenului prin uleiul extras din ficatul de cod, determină lipsa vindecării afecțiunilor oftalmice, dar îşi păstrează capacitatea de a vindeca rahitismul. În acest fel, Elmer McCollum a concluzionat că vindecarea rahitismului se datorează unei vitamine noi, pe care a numit-o vitamina D (1).

Deficitul de vitamină D reprezintă o problemă de sănătate din ce în ce mai frecvent întâlnită în practica medicală, având implicații fie în declanşarea unor boli, fie în menţinerea şi agravarea acestora. Deficitul de vitamină se apreciază pe baza determinării nivelului seric de $25-(\mathrm{OH})$-vitamina $\mathrm{D}$, metabolit rezultat prin acțiunea 25-hidroxilazei hepatice. Deşi nu există un consens asupra valorilor normale de $25-\mathrm{OH}$ vitamina $\mathrm{D}$, se defineşte deficitul de vitamină D printr-un nivel seric $<20 \mathrm{ng} / \mathrm{ml}$ (50 nmol/1). Valorile $<10 \mathrm{ng} / \mathrm{ml}$ indică un deficit sever. Valorile cuprinse între 20 şi $29 \mathrm{ng} / \mathrm{ml}$ reprezintă un indicator de insuficiență relativă a vitaminei $\mathrm{D}$, în timp ce un nivel $>30 \mathrm{ng} / \mathrm{ml}$ este considerat un nivel normal. Apariția frecventă a deficitului de vitamină D este cauzată atât de deficitul alimentar în vitamina $\mathrm{D}$, cât şi de limitarea expunerii la soare sau expunerea însoțită de folosirea în exces a produselor de protecție la acțiunea razelor ultraviolete, deficit de absorbție a vitaminei $\mathrm{D}$, deficit de hidroxilază hepatică sau renală, necesară în procesul de activarea a vitaminei D (vezi Tabelul 1).

TABELUL 1. Cauzele deficitului de vitamină $D$

\begin{tabular}{|l|l|}
\hline & Cauza deficitului de vitamină D \\
\hline 1 & Aport alimentar deficitar \\
\hline 2 & Expunerea insuficientă la soare \\
\hline 3 & Folosirea excesivă a protecţiei solare \\
\hline 4 & $\begin{array}{l}\text { Deficit de absorbţie (afectare hepa că, pancrea tă, boală } \\
\text { Crohn, boală celiacă, fibroză chis că) }\end{array}$ \\
\hline 5 & $\begin{array}{l}\text { Afecţiuni hepa ce ce determină reducerea ac vităţii } \\
25 \text {-hidroxilazei }\end{array}$ \\
\hline 6 & $\begin{array}{l}\text { Afecţiuni renale ce determină reducerea ac vităţii } \\
1 \alpha \text {-hidroxilazei }\end{array}$ \\
\hline 7 & $\begin{array}{l}\text { Creşterea catabolismului vitaminei D (hiperpara roidism, } \\
\text { medicamente) }\end{array}$ \\
\hline 8 & $\begin{array}{l}\text { Pierderi crescute de vitamină D (sindrom nefro c, dializă } \\
\text { peritoneală) }\end{array}$ \\
\hline
\end{tabular}

Deficitul de vitamina D apare la anumite categorii de persoane, considerate a fi la risc, şi anume: sugarii, adolescenții, femeile gravide, femeile care alăptează şi cei peste 50 de ani (vezi Tabelul 2). De asemenea, pentru aprecierea riscului de apariție a deficitului de vitamina $\mathrm{D}$, se iau în considerare zona geografică în care locuiesc (riscul creşte cu creşterea latitudinii şi scăderea gradului de însorire), persoanele cu tegument hiperpigmentat, pacienții obezi sau cu boli cronice severe, cei care sunt în tratament cronic cu anumite medicamente (3) (vezi Tabelul 3), precum şi nou-născuții ce provin din mame cu deficit de vitamin D.

TABELUL 2. Categorii aflate la risc pentru deficit de vitamină $D$

\begin{tabular}{|l|l|}
\hline & Categoria de risc \\
\hline 1 & Sugari \\
\hline 2 & Adolescenţi \\
\hline 3 & Femei gravide \\
\hline 4 & Femei care alăptează \\
\hline 5 & $\begin{array}{l}>50 \text { ani, } \\
\text { Risc crescut }>65 \text { ani }\end{array}$ \\
\hline
\end{tabular}

TABELUL 3. Medicamente care interferă cu vitamina $D$

\begin{tabular}{|l|l|}
\hline $\begin{array}{l}\text { Medicamente care scad nivelul } \\
\text { vitaminei D }\end{array}$ & $\begin{array}{l}\text { Medicamente care cresc } \\
\text { nivelul vitaminei D }\end{array}$ \\
\hline $\begin{array}{l}\text { An epilep ce (fenobarbital, } \\
\text { fenitoină, acid valproic) }\end{array}$ & Sta ne \\
\hline Orlistat & Diure ce azidice \\
\hline An tuberculosta ce (rifampicina) & \\
\hline Cor coizi (dexametazona) & \\
\hline $\begin{array}{l}\text { Citosta ce (Ciclofosfamidă, Taxol, } \\
\text { Tamoxifen) }\end{array}$ & \\
\hline $\begin{array}{l}\text { Sechestranţii de acizi biliari - } \\
\text { rezinele (coles ramina, coles pol) }\end{array}$ & \\
\hline
\end{tabular}

Studiile recente asociază deficitul de vitamină D cu procesele metabolice şi imunologice, cu rol în special de promovare a stării fiziologice a celulelor. Vitamina D a fost definită drept modulator imunitar natural, acționând după activarea receptorilor de vitamină D (VDR) prin reglarea metabolismul calciului, creşterea celulară, proliferarea şi apoptoza şi alte funcții imunologice.

Receptorul pentru vitamina D(VDR) este o proteină implicată în homeostazia calciului şi, de asemenea, în turnover-ul osos, fiind localizat intracelular, la nivelul nucleului. VDR se leagă în mod specific de 1,25 (OH)2 vitamina D3 (calcitriol) şi mediază efectele acesteia. Funcția VDR-ului constă în transcrierea a mii de gene, inclusiv cele pentru peptidele antimicrobiene - antibioticele organismului de spectru larg produse natural. Ele au o importanţă crucială atât pentru prevenirea, cât şi pentru eliminare infecției (4).

Datele epidemiologice subliniază o corelaţie puternică între deficitul vitaminei D şi riscul crescut pentru bolile inflamatorii cronice de diverse etiolo- 
gii, inclusiv bolile autoimune. Studiile epidemiologice şi genetice au indicat un rol potenţial al vitaminei D în patogeneza anumitor boli autoimune sistemice: lupus eritematos diseminat, artrită reumatoidă, scleroză multiplă, diabet zaharat, ciroză biliară primară. Aceste studii demonstrează corelația între deficitul de vitamină D şi prevalenţa acestor bolilor. Polimorfismele receptorului VDR observate în aceste boli autoimune susţin în continuare legătura patologică. Suplimentar, s-a observat corelaţia dintre nivelul seric de vitamină D şi manifestările clinice şi/sau activitatea bolilor (5).

Studiile epidemiologice arată că un nivel seric adecvat de vitamină $\mathrm{D}$ reduce riscul de modificări cancerigene la nivelul mucoaselor, riscul de cancer de sân şi de prostată. Acțiunea 1,25 (OH)2 vitamina D3 şi prezența VDR intracelular la nivelul celulelor cancerigene influențează procesele de proliferare, diferenţiere, apoptoză şi reducerea angiogenezei (6).

Datelele sunt contradictorii privind prevenţia apariţiei diferitelor cancere (sân, colon, prostată) prin administrarea suplimentară de vitamină D. Sunt necesare studii suplimentare pentru a dovedi în mod cert rolul benefic al suplimentării cu vitamină D în prevenirea afecțiunilor oncologice (7).

Deficitul de vitamină D se asociază atât cu riscul de a dezvolta diabet zaharat de tip 1, cât şi cu riscul de a dezvolta diabet gestațional (8). Vitamina $D$ reduce incidența inflamației de la nivelul insulelor pancreatice Langerhans şi previne dezvoltarea diabetului de tip I la animalele de laborator, doar dacă vitamina D se administrează şoriceilor înainte de debutul inflamației.

Deficitul sever de vitamină D creşte riscul de apariție al diabetului zaharat de tip II, al sindromului metabolic, dar şi riscul de mortalitate cardiovasculară. Mecanismele de acțiune ale vitaminei D includ efectele sale antiinflamatorii, secreția crescută de insulină prin stimularea celulelor $\beta$ pancreatice şi scăderea nivelului de hormoni paratiroidieni (10).

Studierea unei cohorte din studiul Framingham s-a făcut prin măsurarea nivelului de 25-hidroxivi- tamină D la participanții fără boală cardiovasculară cunoscută inițial şi apoi la 5 ani. S-au urmărit evenimentele cardiovasculare (infarct miocardic, angină, accident vascular cerebral, insuficiență cardiacă). S-a măsurat un risc de evenimente cardiovasculare mai mare cu $62 \%$ la pacienții cu hipertensiune arterială al căror nivel de 25-hidroxivitamina $\mathrm{D}$ a fost mai mic de $15 \mathrm{ng} / \mathrm{ml}$, în comparație cu cei al caror nivel a fost peste $15 \mathrm{ng} / \mathrm{ml}$ (11).

Prin acțiunea 1,25 (OH)2 vitamina D3 asupra VDR se reduce expresia genei care codifică renina, determinând astfel reducerea tensiunii arteriale. Multe studii clinice şi epidemiologice au arătat posibilele roluri ale vitaminei D în controlul tensiunii arteriale. $\mathrm{Cu}$ toate acestea, rezultatele metaanalizelor nu susțin utilizarea vitaminei D sau a analogilor săi ca tratament individual al pacientului pentru hipertensiune arterială sau ca intervenție la nivel de populație pentru scăderea tensiunii arteriale (12).

Studiile prospective de cohortă indică o creştere neliniară pentru evenimentele cardiovasculare la niveluri de circulație a 25 -hidroxivitaminei $\mathrm{D}$ sub $50 \mathrm{nmol} / 1$ (13).

\section{CONCLUZII}

Datorită prezenței intranucleare a VDR la nivelul tuturor celulelor şi implicarea acestuia în transcrierea a mii de gene, simptomele şi semnele deficitului de vitamină $\mathrm{D}$ sunt multiple, prin interacțiunea cu funcția mai multor sisteme şi organe. Studiile clinice şi epidemiologice nu arată un consens în ceea ce priveşte prevenirea apariției bolilor prin administrare de vitamină $\mathrm{D}$, dar se mențin în asocierea multiplă dintre existența deficitului de vitamină D şi apariția bolilor autoimune, cardiovasculare sau diferite afecțiuni oncologice. Având în vedere aceste lucruri, se impun identificarea grupelor populaționale cu risc de deficit de vitamină D şi administrarea profilactică a vitaminei $\mathrm{D}$ la aceste grupe populaționale.

Conflict of interest: none declared Financial support: none declared

\section{BIBLIOGRAFIE}

1. DeLuca H.F. History of the discovery of vitamin $D$ and its active metabolites. BoneKEyReports, (2014)3,479

2. WHO Vitamin and mineral requirements in human nutrition, second edition-WHO library, ISBN 9241546123

3. Grober U., Kister K. Influence of drugs on vitamin D and calcium metabolism. Dermatoendocrinol, 2012 Apr 1; 4(2): 158-166.

4. Pike W., Meyer M. The vitamin D receptor: New paradigms for the regulation of gene expression by 1,25-dihydroxyvitamin $D_{3}$. Endocrinol Metab Clin North Am. 2010 Jun; 39(2): 255-269

5. Agmon-Levin N., Theodor E., Segal R.M. et al. Vitamin D in systemic and organ-specific Autoimmune diseases. Allergy\&Immunology, October 2013, Volume 45, 2, pp 256-266 
6. Gandini S., Boniol M., Haukka J. et al. Meta-analysis of observational studies of serum 25-hydroxyvitamin D levels and colorectal, breast and prostate cancer and colorectal adenoma. International Journal of Cancer. 2011;128(6):1414-1424.

7. Chung M., Lee J., Terasawa T. et al. Vitamin D with or without calcium supplementation for prevention of cancer and fractures: An updated meta-analysis for the U.S. Preventive Services Task Force. Annals of Internal Medicine. 2011;155(12):827-838.

8. Benetti E., Mastrocola R., Chiazza F. et al. Effects of vitamin d on insulin resistance and myosteatosis in diet-induced obese mice. PLoS One, 2018 Jan 17;13(1)

9. Mohamadpour S., Sayehmiri K., Mousavi S.F. et al. Effects of vitamin $\mathrm{D}$ deficiency on incidence risk of gestational diabetes mellitus:
A systematic review and meta-analysis. Front Endocrinol (Lausanne). 2018 Feb 1;9:7.

10. Thomas G.N., Hartaigh B., Bosch J.A. et al. Vitamin D levels predict all cause and cardiovascular disease mortality in subjects with the metabolic syndrome (LURIC Study). Diabetes Care, 2012 35:1158

11. Wang T.J., Pencina M.J., Booth S.L. et al. Vitamin D deficiency and risk of cardiovascular disease. Circulation. 2008:117(4):503-511.

12. Jeong H.Y., Park K.M., Lee M.J. et al. Vitamin D and hypertension. Electrolyte Blood Press, 2017 Sep; 15(1): 1-11

13. Zittermann A. Vitamin d status, supplementation and cardiovascular disease. Anticancer Res, 2018 Feb;38(2):1179-1186 